\title{
THE SECOND CONFLICTS RESTATEMENT: A LAST APPEAL FOR ITS WITHDRAWAL
}

\section{ALBRRT A. EHRENZWEIG $\dagger$}

In 1934 the "Restatement" of the Law of Conflict of Laws was offered to the profession as "a statement of the existing state of the common law." 1 That it never was such a statement has always been widely recognized ${ }^{2}$ and has now been admitted by the American Law Institute. $^{3}$ But it took a whole generation of scholars to destroy that unfortunate product of misguided idealism ${ }^{4}$ and obsolete doctrine, ${ }^{5}$ out of whose "wreckage," in the words of Chief Justice Traynor, today's judge still "must chop his own way through." 8 And it will be some time yet until the rubble-judicial language based on false doctrinewill have been cleared away.

One might have hoped that this distressing result of an ill-conceived experiment would have precluded renewal of the effort to produce a Restatement. It was with serious misgivings, therefore, that some of us learned more than a decade ago of the start of a similar venture. And it was some of these misgivings that I expressed in this Review when I urged abandonment of that venture. ${ }^{7}$ Yet ever since, Draft has followed Draft, and we must now expect submission of an entire Second Restatement for final adoption.

$\uparrow$ Walter Perry Johnson Professor of Law, University of California at Berkeley.

12 ALI Procerdings 21 (1924). See also Goodrich, The Story of the Americat Lave Institute, 1951 WASE. U.L.Q. 283, 290.

2 See note 40 infra.

3 See note 26 infra.

${ }^{4}$ See, e.g., Ehrenzweig, Treatise on the Conflict of Laws $\$ 4$ n.18 (1962) [hereinafter cited as TREATISE].

5 See $i d . \S \S 2-4,107$.

6 Traynor, Law and Social Change in a Democratic Society, 1956 U. ILL. L.F. $230,234$.

7 Ehrenzweig, American Conflicts Law in Its Historical Perspective: Should the Restatement Be "Contimued"? 103 U. PA. L. REV. 133 (1954). See also Ehrenzweig, El "Restatement" de "Conflict of Larvs", 5 BolETIN DEI. INSTITUTO DE Derecho Comparado de MÉxico 258 (1952) ; Ehrenzweig, El "Restatement" americano del conflicto de derechos: Historia de un fracaso, 3 CuAdernos DERECHos ANGLoAMERICANo 37 (1955) ; Ehrenzweig, Su un profilo storico dei conflitti di leggi in America, 9 Jus, Revista de ScIEnze GIURmICHe 519 (1958); Ehrenzweig, American Private International Law and the "Restatement", 28 NORDISK TIDSSKRIFT FOR INT'L RET 229 (1958) ; Ehrenzweig, Zum Handzerkszeng des amerikanischen internationalen Privatrechts, 7 ÖSTERREICHISCHE ZEITSCHRIFT FÜR ÖFFENTLICHES RECHT 521 (1956). 
During this period, in several books and numerous articles, ${ }^{8} \mathrm{I}$ have analyzed in detail the project as it progressed and have been confirmed in my doubts by such scholars as Arthur Corbin who has strongly disapproved the Second Restatement's entire approach, ${ }^{9}$ and Brainerd Currie who has stated that "at this stage we certainly do not need a new Restatement, although we are threatened with one." 10 Indeed, there is the danger that another Cook and another Lorenzen will have to spend their life's work to undo this new Restatement-a sacrifice American scholarship can ill afford. For that document, despite the valiant efforts of an able draftsman, may well parallel its predecessor as a hindrance to the sound development of the common law. And again this hindrance could prove particularly serious abroad $^{11}$ and in those American jurisdictions which, lacking precedent, would again be tempted to treat the Institute's announcements as primary authority. ${ }^{12}$ It was for these reasons that I recently submitted to the Council a "Last Appeal" for the appointment of a special commission consisting of particularly qualified judges, lawyers and scholars, ${ }^{13}$ which would be asked to reexamine the Draft to determine whether any second restatement is desirable at this time, and, if it is, how the present draft could be improved in collaboration with the Reporter and his advisers. With a view to such possible improvements I suggested the following questions for consideration: (1) whether the Draft should not be expressly limited to interstate conflicts; (2) whether it should not be revised with a view to achieving greater theoretical consistency; (3) whether it should not be revised to respond to current doctrine; and, (4) whether in any event it should not be

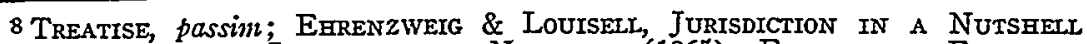
(1964); EHRENZWEIG, Conflicts iN A Nutshell (1965); EhrenzWeig, Fragistas \& Yannopoulous, AMrerican-Greek Provate International Law (1957); EmrenzWeig, Ikeharat \& Jensen, Amertcan-Japanese Private International Law (1964). The following articles published with the subtitle "Law and Reason Versus the Restatement Second" are also pertinent in part: Ehrenzweig, Miscegenation in the Conflict of Laws, 45 CoRNell L.Q. 659 (1960) ; Ehrenzweig, The "Most Significant Relationship" in the Conflicts Law of Torts, 28 LAW \& CoNTEMP. PROB. 700 (1963); Ehrenzweig, Restitution in the Conflict of Laws, 36 N.Y.U.L. REv. 1298 (1961). For a bibliography, see Symposium-Ehrenzweig's Proper Forum and Proper Laze, to be published in Volume 18 of the Oklahoma Law Reviez.

8 See Ehrenzweig, Conflicts in a Nutshell $\$ 8$ (1965), containing extensive extracts from Corbin's letters, published with his authorization.

10 Currie, The Disinterested Fornm, 28 LAw \& CoNTEMr. Prob. 754, 755 (1963). See also Cavers, Re-stating the Conflict of Laws: The Chapter on Contracts, in XXTH Century Comparative and Conflicts Law 349, 364 (1961).

11 See text at notes 15-22, infra.

12 See, e.g., Ehrenzweig, The Restatement as a Source of Conflicts Law in Arizona, 2 ARIz. L. REV. 177 (1960). Concerning the Restatement's general claim to such authority, see Goodrich, sispra note 1 , at 290.

13 Among many others Black, Breitel, Brown, Friendly, Fuld, Harlan, Hastie, Heffernan, Kaufman, Kenison, O'Connell, Roberts, Schaefer, Sobeloff, Tate, Traynor, and Wyzanski, JJ., and Professors Cavers, Currie, Hancock, Leflar, Rheinstein, Von Mehren, and Yntema would no doubt have been on the list of those invited. 
limited to those narrow propositions which are settled by judicial practice (rather than mere language), and accompanied by an express "repeal" of the First Restatement. ${ }^{14}$

The Council did not find any of these suggestions acceptable. And at its May meeting the Institute approached final adoption of its nearly completed project. My purpose then in this present publication is to establish, for those courts and lawyers who in the future will be asked to "apply" the provisions of the new "restatement," that this document, like its predecessor, does not reflect the "communis opinio" of either courts or scholars. The fact that the Drafts may be credited for many improvements over the First Restatement might have made them preferable to the latter at the time of its publication, but it does not justify the adoption of a Second Restatement at this time. Not only is this new experiment beset by theoretical difficulties similar to those which have discredited its predecessor, but many new specific provisions will inevitably add to the confusion created by the original version. My "last appeal" has to be brief and must therefore rely on earlier writings for documentation.

\section{Should the Draft Not Be Expressly Limited to Interstate CONFLICTS?}

Perhaps due to a widespread misconception of the Institute as an official agency, and the great attraction of any black-letter text for code-trained lawyers, ${ }^{15}$ the Restatement has been translated into foreign languages ${ }^{16}$ and has received full recognition abroad as the principal source of American law. ${ }^{17}$ Thus all over the world comparative law institutes acting as official court experts have treated the Restatement as conclusive evidence of American international conflicts law. This is hardly compatible with the Institute's own belief that "the rules of law in the Restatement of the subject are perhaps better fitted to interstate than to inter-foreign transactions." 18 Indeed, in many respects constitutional and other considerations require a separate treatment of inter-

14 There would have been precedent for the proposed procedure. The First Restatement, because of a "violent controversy . . . was held for two years' additional time and reexamined by the Institute's Executive Committee." Goodrich, supra note 1 , at 288 .

15 This reaction is particularly regrettable in the communist countries in view of the still prevailing difficulty in communication. See, e.g., TREATISE $\$ 123$, at $351 \mathrm{n} .3$, for the Russian conception of the conflicts restatement as an "inofficial code." For an historical curiosity see also such decisions of American Occupation courts as Turner v. Dinges, 7 U.S. Courts of the Allied High Comm'n for Germany 90, 91 (1949).

16 See, e.g., ALI ANN. REP. 24-27; 1942 ALI ANN. REP. 16; 1948 ALI ANN. Rep. 8; Restatement IN the Courts 22 (1945).

${ }_{17}$ "The [Conflicts] Restatement abroad as a definitive source of American law is : noteworthy"; "standard reference in civil law countries." Goodrich, in 1948 ALI ANN. REP. 7.

18 Restatement in the Courts 11 (1945). See also 1 ALI Proceedings 66-67 (1923); 4 ALI PROCEEDINGS 254-69 (1926). 
national conflicts, ${ }^{19}$ and such a treatment may even vary according to the foreign country involved, as is dramatically illustrated by the success of the Parker Institute's series of bilateral studies. ${ }^{20}$ It is particularly significant in this context that the Reporter of the Second Restatement at one point expressed his personal view that the Draft, except where its text clearly indicates otherwise, should be read as referring only to interstate conflicts. ${ }^{21}$ To be sure, examination may very well show that in some areas American courts apply the same general principles in both international and interstate cases. But until such an examination has been made-and it has never yet been attempted-an express exclusion of international conflicts seems in order to avoid further misunderstandings both abroad and at home. Indeed, a statement to that effect seems imperative at this time when the United States Government has decided to participate in the work of the Hague Conference on Private International Law and when efforts are being continued for an interamerican harmonization of conflicts law. We must make certain that these international ventures cease to treat the Restatement as a correct summary of this country's international conflicts law. ${ }^{22}$

19 See Ehrenzweig, Interstate and International Conflicts Law: A Plea for Segregation, 41 MINN. L. REv. 717 (1957); and virtually all foreign reviews of my TREATISE, listed in Symposium, supra note 8. Against the proposed separate treatment it is tempting to argue that two important recent decisions which involved international conflicts, have become leading in interstate cases. But Auten v. Auten, 308 N.Y. 155, 124 N.E.2d 99 (1954), though now generally relied on for a general theory of the "most significant relationship" probably did not involve conflicting laws and, if it did, was determined by the forum's distaste for forfeitures, see TREATISE $\$ 183$, at 487; and Babcock v. Jackson, 12 N.Y.2d 473, 240 N.Y.S.2d 743, 191 N.E.2d 279 (1963) concerned the "guest statute" of an adjoining Canadian province and thus presented a conflict entirely analogous to those existing between sister states. See Comment, 63 Colum. L. Rev. 1212 (1963).

20 This series has grown to include thirteen countries: Australia (Cowen, 1957), Austria (Seidl-Hohenveldern, 1963), Brazil (Garland, 1959), Chile (Etcheberry, 1960), Colombia (Eder, 1956), Denmark (Philip, 1957), France (Delaume, 1953, 1961), Germany (Domke, 1956), Greece (Ehrenzweig, Fragistas and Yiannopoulos, 1957), Japan (Ehrenzweig, Ikehara and Jensen, 1964), Sweden (Nial, 1965), and Switzeriand (Nussbaum, 1951, 1958).

21 See the authorized quotation in Ehrenzweig, Interstate and International Conflicts Laze: A Plea for Segregation, 41 MiNN. L. Rev. 717 (1957). But cf. RestateMENT (SECOND), CONFLICT OF LAwS \$ 5a (Tent. Draft No. 12, 1965), which declares the Restatement rules applicable to "international Conflict of Laws cases unless the factors in the particular case call for a result different from that which would be reached in an interstate case." "Some differences in factors" are enumerated in comment $d$ on a purely academic level without citation of authority.

22 See, e.g., Comparative Study of the Bustamente Code, the Montevideo Treaties, and the Restatement of the Conflict of Lares, O.A.S. INTER-AMERICAN JURIDICAL ComrairteE (CIJ-21) (1954). Most important, we must not bar the way to a national law that the Supreme Court may yet sanction "in ordering our relationships with other members of the international community. . . " Banco Nacional de Cuba v. Sabbatino, 376 U.S. 398, 425 (1964). See also the dictum in United States v. Belmont, 301 U.S. 324,331 (1937): "in respect of our foreign relations generally . . . state lines disappear."

Such a development towards a "national law" is increasingly likely in view of the fast-growing demand for a "transnational law" in world commerce. See, e.g., Yntema, Basic Issues in Conflicts Law, 12 AM. J. Comp. L. 474, 482 (1963). 


\section{Should the Draft Not Be Revised With a View to Achieving Greater Theoretical Consistency?}

Professor Cavers has summarized his criticism of the Contracts chapter of the Draft by pointing out its "want of a consistent conception of the choice-of-law problem." ${ }^{23}$ This criticism applies also to the Draft as a whole insofar as it postulates (a) a "legislative jurisdiction" to be ascertained by (b) a "neutral forum" in potential disregard of such concededly nonrestatable considerations as might lead "interested states," by a weighing of (c) "massed" "contacts," with the help of (d) various "structural" devices, to reach a law other than that postulated by the Draft as "most appropriate."

\section{A. "Legislative Jurisdiction"}

Under Professor Beale's vested rights theory, legislative jurisdiction denoted a "power" conferred on certain states "to create interests which under the principles of the common law will be recognized as valid in other states." 24 The Draft has discarded the vested rights theory as well as the underlying fiction of a super-law. It has recognized that any "decision to apply the law of a particular state is in effect a holding that that state has jurisdiction," and that, in view of the absence of constitutional control, ${ }^{25}$ even a state with "lesser contacts" may thus be attributed concurrent "jurisdiction" by any forum. ${ }^{26}$ It appears, therefore, that the concept of legislative jurisdiction has, as the creation of each forum, now become a necessarily misleading synonym for any "eligible law." 27

23 Cavers, supra note 10.

24 Restatement, Conflict of Laws $\$ 42$ (1934). For fuller discussion, see Treatise $\$ \S 12-13$.

25 The only case that Restatement (Second), Confict of Laws at 20 (Tent. Draft No. 3, 1956) properly cites as supporting such constitutional control is Home Ins. Co. v. Dick, 281 U.S. 397 (1930). The merely negative prohibition of that case fails to establish an affirmative concept of legislative jurisdiction. See TrEATISE $\$ 9$; EHRENZWEIG, CoNflicts in a Nutshelt $\$ \$ 12,13$ (1965).

${ }_{26}$ The Draft has expressly abandoned the Restatement's principal foundation in an "analytical jurisprudence" at variance with the Institute's basic plan to proceed "from precedent, from analogy, from legal reason, and from consideration of ethical and social need." Restatement (Second), Conflict of Laws 3 (Tent. Draft no. 6, 1960).

27 This tautology appears particularly in many passages of the earlier drafts. See, e.g., Restatement (Second), Conflict of Laws 21 (Tent. Draft No. 3, 1956) ("a state's law cannot validly be applied to create or affect legal interests unless that state has legislative jurisdiction") ; or id., at $\$ 42(1)$ ("a state may create or affect legal interests whenever its contacts with a person, thing, or occurrence are sufficient to make such action reasonable"). We learn that the tort law of state $X$ will never be applied in state $\mathrm{Y}$ to an accident in that state in a suit there (even where both parties are forum citizens) because "X lacks legislative jurisdiction to apply its tort law to this particular occurrence." Id. at 4. Does the denial of legislative jurisdiction mean more here than that $Y$ does not have a conflicts rule calling for the application of $\mathrm{X}$ law? For similar tautologies, see, e.g., RESTATEMENT (SECOND), CONFLICT of LAws $\S 151$ (b), at 16 (Tent. Draft No. 7, 1962); and for effective criticism, 1956 AII PRoceedings 468 et seq. 


\section{B. The "Neutral Forum" and "Interested States"}

The Reporter informs us that the Draft was "written from the viewpoint of a neutral forum which has no interest of its own to protect and is seeking only to apply the most appropriate law." 28 Since this theory assumes an objectively ascertainable "most appropriate law," it would in effect restore the fiction of vested rights and is thus inconsistent with the Draft's own new, wholly relative, concept of legislative jurisdiction.

To be sure, this inconsistency would by itself not be too disturbing if it were limited to cases "in truly neutral forums." But since, as the Reporter realizes, such cases "rarely arise," ${ }^{29}$ the Second Restatement does in effect, contrary to its avowed theoretical commitment, purport to state the conflicts rules of non-neutral "interested" fora. ${ }^{30}$ This is fatal to the Draft's very conception since, as the Reporter properly concedes, some of the considerations prevailing in interested fora "that will induce a court to apply its own local law rather than that of another state ["the most appropriate law"] are many and varied and are not susceptible to restatement." 31 The Reporter's concession also implies an admission of defeat for that pervasive technique of the Second Restatement which seeks to ascertain law "governing" certain transactions by what Professor Cavers has stigmatized as a "jurisdiction-selecting" approach. ${ }^{32}$

\section{C. "Massed Contacts" and Forum Policies}

The most recent installments of the Draft are replete with references, interchangeably used, to "contacts," "connections," and "rela-

28 Reese, Conflict of Lazes and the Restatement Second, 28 LAw \& ConTEMr. Prob. 678, 692 (1963).

$29 \mathrm{Id}$. at 692-93.

30 See, e.g., Restatearent (Second), Conflict of Laws $\$ 379$ (3) (Tent. Draft No. 9, 1964); id. \$379a, at 21. This "interest" language, foreign to earlier drafts, has apparently been borrowed from Currie's theory of "governmental interests." See generally CurrIe, Selected EsSAYS oN the Conflicts of LAwS (1963). But it should be noted that the Draft's usage does not accord with the originator's terminology. See among many other instances, Restatement (Second), Conflict of LAws $\$ 379 \mathrm{a}$, comment $e$ at 21 (Tent. Draft No. 9, 1964): "The state where conduct occurs has the greatest interest in regulating it and determining whether it is tortious in character." This indeed is the vested rights doctrine in a new disguise. Currie, supra note 10 , at 776. See also RESTATEMENT (SECOND), Conflict of Laws 94 (Tent. Draft No. 4, 1957) ("paramount interest"); RESTATEMENT (SECOND), CoNFLICT of Laws $\$ 8$, comment $k$ (Tent. Draft No. 12, 1965) ("dominant interest"). See generally id. \& 6. Cf. Ehrenzweig, Choice of Law: Current Doctrine and "True Rules", 49 CALIF. L. Rev. 240, 243-48 (1961) ; Ehrenzweig, A Proper Laze in a Proper Forum: $A$ "Restatement" of the "Lex-fori Approach", to be published in Volume 18 of the Oklahoma Laze Revieze.

31 Reese, supra note 28, at 692. (Emphasis added.)

32 See, e.g., Cavers, supra note 10, at 350 . For further compelling criticism, see Currie, The Disinterested Formm, 28 LaW \& ConteMr. ProB. 754, 765-66 (1963). 
tionships" and their "massing." Concurrently we are referred to "the relevant purposes of the . . . rules of the interested states," 38 which apparently are identical with what prevailing opinion and occasionally the Draft itself calls "policies." 34 This is not the place for defending my own view that the only possibly relevant policy is that of the forum, ${ }^{35}$ since reference to another state's policy presupposes a choice of the law of that state, and since that choice in turn must be based on the forum's policy (though that policy is of course frequently an "altruistic" one). But it seems clear that the consideration of (forum or foreign) policies is the very essence of choice of law and cannot simply be contrasted with "contacts." If the "significance" of those contacts were to be considered independently from policy, as the Draft seems to suggest, ${ }^{36}$ we would, indeed, have to complain with Professor Currie that

surely we cannot go on indefinitely speaking of "significant contacts" without asking and answering the question: Significant for what? . . . It cannot be too often repeated that the significance of the ways in which a state is related to the parties, the events, the property, or the litigation cannot be determined without reference to some standard-a standard that the Restatement (Second) conspicuously neglects to supply. ${ }^{37}$

\section{D. "Structure" of Choice of Lawe}

Throughout the Draft we find references to such concepts and techniques as characterization and renvoi ("whole law"). Elsewhere I have analyzed these concepts and techniques as unwelcome importations from continental countries which have themselves either abandoned them or are in the process of doing so. ${ }^{38}$

33 See, e.g., Restatement (Second), Conflict of Laws $\$ 379(3)$ (Tent. Draft No. 9, 1964).

34 See, e.g., Restatement (Second), Conflict of Laws $\$ 332 a$ (1) (c) (Tent. Draft No. 6, as modified Nov. 15, 1960).

35 I have last defended this view in EmREnzweig, Conflicts in a NutshecL $\S \S 8,9$ (1965).

36 But see Wilcox v. Wilcox, 133 N.W.2d 408, 417 (Wis. 1965).

37 Currie, Full Faith and Credit Chiefly to Judgments: A Role for Congress, 1964 Supreme Court Rev. 89, 95. See text at notes 70-77, infra.

38 Ehrenzweig, Characterization in the Conflict of Laws: An Unwelcome Addition to American Doctrine, in XXTH Century Comparative and Conflicts Law 395 (1961). But see Restatement (SECOND), Conflict of Laws \$ 7 (Tent. Draft No. 12, 1965). For its novel renvoi theory (id. §8) the Reporter (id. at 34) claims the support of "the more modern writers"-to the exclusion of Scoles" 1965 edition of Goodrich, of Stumberg's 1963 edition, of Leflar's 1959 text and of the Treatise as well as of the leading cases. 


\section{Should the Draft Not Be Revised To Respond to Current DOCTRINE?}

The Institute had intended to avail itself of "the labors of the foremost scholars." 39 This attempt was abandoned in the field of conflicts law for both restatements. Not only did most leading scholars refrain from participating in the First Restatement-names like Cavers, Cook, Leflar, Lorenzen, Stumberg, and Yntema immediately come to mind-, but many of them actively opposed its adoption. ${ }^{40}$ Ernst Rabel, from whose support the Institute had expected so much, in due course found the Restatement the "exact antipode of private international law [and] entirely destroyed by Lorenzen and Cook." 41 And there still rings in our ears Hessel Yntema's indictment of the Restatement for its deviation from existing law by

(1) nonstatement of relevant, substantiated doctrine, (2) nonstatement of relevant legislative trends, (3) statement of nonsubstantiated doctrine, (4) statement as existing law of doctrine repealed in the majority of American jurisdictions, (5) inaccurate statement of existing precedents, (6) acceptance of inappropriate and questionable English precedents as authority. ${ }^{42}$

In the list of advisers to the Reporter of the Second Restatement we miss again such names as Cavers, Currie, Hancock, Leflar, Rheinstein, Stumberg, Von Mehren, and Yntema, in addition to almost the entire generation of younger scholars. Such argumenta ad hominem are painful, but they cannot be avoided at this critical stage.

Perhaps even more significant than the Draft's failure to respond to current doctrine, is the fact that the Institute's Council itself appears to have failed to achieve even substantial agreement concerning the very basis of those parts of the Draft which most prominently reflect its new approach. Reportedly, the Council approved the "most significant relationship" test of contracts law, which has since become the basis of the torts chapter as well, by a mere majority of thirteen to twelve! ${ }^{43}$

392 ALI Procendngs 21 (1924).

40 See, e.g., Yntema, The Restatement of the Laze of Conflict of Lazes, 36 Corun. L. Rev. 183 (1936); Cavers, $A$ Critique of the Choice-of-Laze Problem, 47 HARv. L. REv. 173, 178-79, 208 (1933), in addition to what may be considered the life work of Cook and Lorenzen.

411 Rabex, Conflict of Laws 14 (2d ed. 1958).

42 Yntema, supra note 40, at 222.

43 Restatement (Second), Conflict of Laws 30 (Tent. Draft No. 6, 1960). 


\section{Should the Draft Not Be Limited to Those Narrow Propositions Which Are Setrled in Light of Judicial Practice (Rather Than Mere Language)?}

There are of course many propositions in the Draft which accurately reflect judicial practice. This is true for much of Tentative Drafts Numbers Five and Thirteen (Property). But many other provisions of the Draft lack supporting authority. Most of the cases relied on are inconclusive because they fail to involve conflicting laws or do not actually apply the "rule" invoked, and are thus cited merely for their language rather than their result. ${ }^{44}$ This technique is particularly hazardous in conflicts law where judicial language is primarily based on a doctrinal terminology whose meaning has changed repeatedly through a period of more than half a millennium, and which, insofar as it involves cases of the last few decades, often invokes Restatement formulas now discarded. I have tried to prove these assertions by an analysis of almost ten thousand cases. ${ }^{45}$ All I can do at this point is (a) to analyze a few typical examples of the Draft's use of authority, (b) to characterize in light of these examples some of the Draft's individual installments, and (c) to take issue with the argument that those provisions of the Draft which lack authoritative support state desirable law and are thus likely to furnish welcome guidance to the courts.

\section{A. Examples for the Draft's Use of Authority}

(1) Section $379 \mathrm{k}$ would ordinarily subject malicious prosecution and abuse of process to the "local law of the state where the proceedings complained of occurred." But none of the cases relied on justifies the proposal: Vancouver Book \& Stationery Co. v. L. C. Smith \& Corona Typezeriters ${ }^{46}$ fails to state a conflict (general approach "in conformity with the general thought"); in Siebrand $v$. Eyerly Aircraft Co.," the decision was in accord with the "federal

44 See, e.g., notes 46-51, infra; or Restatement (Second), Conflict of Laws $\$ 354 \mathrm{k}$ (Tent. Draft No. 6, 1960) where we are told that "the law governing the relationship determines the existence and extent of any quasi-contractual obligation," and that this rule "is supported by the reasoning and result" of three cases and "by the result reached" in the great majority of other decided cases. I have tried to show that none of the authorities adduced for these propositions supports the conclusions reached. TREATISE $\S 227$, at 601 n.30. See also $i d$. $\$ 175$, at $466 \mathrm{n} .11$ for Pennsylvania.

$45 I d$., passin. See also Cavers, supra note 10 , criticizing the "erratic pattern - . . lacking in internal coherence" in the Draft's use of authority.

46138 F.2d 635 (9th Cir. 1943), cert. denied, 321 U.S. 786 (1944). See also Jones v. McKesson \& Robbins, Inc., 237 F. Supp. 454 (D.N.D. 1965) (what is "probable cause"?).

47185 F. Supp. 538 (D. Ore. 1960). 
law" and the rule "generally applied"; in International Film Distrib. Establishment $v$. Paramount Pictures Corp.$^{48}$ we can at best find a dictum used to invite a motion to dismiss that apparently was never made; and in Pelella $v$. Pelella, ${ }^{49}$ the pertinent forum rule was expressly said to "conform" with the pertinent foreign law. The only case among those cited in which a potential difference between the potentially applicable laws was mentioned was that of Weiss $v$. Hunna, ${ }^{50}$ which in effect applied the lex fori.51 And why, indeed, should the perpetrator of a malicious prosecution be encouraged to choose a state for his action whose law will protect him against the consequences of his malice?

(2) Section 132 declares that "a marriage is invalid everywhere, even though the requirements of the state where the marriage took place have been complied with, if it is invalid under the law of a state where at least one of the parties is domiciled at the time of the marriage and where both intend to make their home thereafter." 52 According to this rule a marriage validly concluded in Illinois between two Mississippi domiciliaries of different "races" would be invalid in California (which it is not), ${ }^{53}$ if at the time of the marriage they had intended to return to Mississippi, although they later decided to make their home in California. ${ }^{54}$ In the absence of judicial authority for this startling result we are hard put to explain the Institute's action whose sole support is sought in a novel concept of a "state of paramount interest," and which is so obviously contrary to the mood and spirit of our time.

(3) The Second Restatement undertakes no more and no less than to undermine one of the very few positions of certainty and co-

4814 Misc. 2d 203, 155 N.Y.S.2d 767 (Sup. Ct. 1956), aff'd, 13 App. Div. 2d 746, 216 N.Y.S.2d 661 (1961), reargument and appeal denied, 14 App. Div. 2d 531, 218 N.Y.S.2d 939 (1961).

4013 Misc. 2d 260, 176 N.Y.S.2d 862 (Sup. Ct. 1958), aff'd, 9 App. Div. $2 d 897$, 195 N.Y.S.2d 599 (1959).

50312 F.2d 711, 717 (2d Cir.), cert. denied, 374 U.S. 853 (1963), in partial reliance on Treatise $\$ 215$, at 558, 563. In Jones v. McKesson \& Robbins, Inc., 237 F. Supp. 454 (D.N.D. 1965), the court concededly applied its own conception of "the gist of the wrong" as permitting the defense of probable cause.

51 That law is probably in effect applied to all intentional torts. See Willenbucher v. McCormick, 229 F. Supp. 659, 661-62 (D. Colo. 1964) (defamation), in partial reliance on TREATISE $\$ 215$, at 558 . 1957).

52 Restatement (Second), Conflict of Laws § 132, at 116 (Tent. Draft No. 4,

63 See Perez v. Sharp, 32 Cal. 2d 711, 198 P.2d 17 (1948). See generally Treatise $\$ 139$, at 382,387 .

54 Restatement (Second), Conflict of Laws $\$ 132$, comment $b$, at 118 (Tent. Draft No. 4, 1957); see Restatensent, Conflict of Laws $\$ 132$, comment $d$, Illustration 13 (1934); Ehrenzweig Miscegenation of the Conflict of Laws, 45 CoRNeLL L.Q. 659 (1960). 
herence that the Supreme Court has been able and willing to establish in the area of interstate conflicts law. Ever since Justice Holmes' opinion in Fauntleroy $v$. Lum, ${ }^{55}$ it has been clear that the forum's public policy cannot be allowed to defeat enforceability of a sister state judgment. And ever since courts have adhered to this hardwon principle of a matured federalism. Yet, the American Law Institute, following the Reporter's highly controversial theory, ${ }^{56}$ is now prepared to scuttle this achievement in more than tenuous reliance on five judicial opinions none of which represents a majority holding and four of which were rendered in such areas as support, ${ }^{57}$ custody, ${ }^{58}$ and workmen's compensation ${ }^{69}$ suits where the forum may well claim an overriding interest as the parens patriae; ${ }^{60}$ while the last opinion left open as a possible, but now increasingly unlikely, ${ }^{61}$ exception to full faith and credit tax assessments, an historical enclave of alleged governmental concern. ${ }^{62}$ There is thus no authority whatsoever for the startling proposition that "a judgment rendered in one State of the United States need not be recognized or enforced in a sister State if such recognition or enforcement . . . would involve an improper infringement of the interests of the sister State." 63

\section{B. The Several Installments of the Draft}

(1) Tentative Drafts Numbers One, Three, Four, Four (a) and Ten, which deal with Jurisdiction and Judgments, attempt to restate concepts and rules which, insofar as they are determined by the Constitution, are hardly a proper subject of restatements of the common law, and which, insofar as they are not so determined, are apt to mislead since they necessarily ignore the widely differing statutes of the several states. The history under the regime of the First Restate-

55210 U.S. 230 (1908).

56 Reese \& Johnson, The Scope of Full Faith and Credit to Judgments, 49 CoLum. L. REv. 153 (1949), now incorporated in Restatement (SECOND), Conflict of Laws 58,59 (Tent. Draft No. 10, 1964).

57 Yarborough v. Yarborough, 290 U.S. 202, 213 (1933) (Stone, J., dissenting). See TREATrSE $\S 5$, at $14, \S 51$, at $183, \S 56$, at 205 .

58 May v. Anderson, 345 U.S. 528, 535 (1953) (Frankfurter, J., concurring); New York ex rel. Halvey v. Halvey, 330 U.S. 610, 619 (1947) (Rutledge, J., concurring); see TREATISE \$ 87, at 291-92. See also Ehrenzweig, The Interstate Child to be published by the Michigan Law Review.

59 Magnolia Petroleum Co. v. Hunt, 320 U.S. 430 (1943) (Stone, C.J.) (dictum); see TrEatise $\$ 63$, at $220-21$.

60 See $i d$. $\S 56$, at 205 .

61 See $i d$. at $174-75$. (dictum).

62 Milwaukee County v. M. E. White Co., 296 U.S. 268 (1935) (Stone, C.J.)

63 Restatement (Second), Conflict of Laws $\$ 434$ c at 56-59 (Tent. Draft No. $10,1964)$. 
ment, of the provisions on divorce, ${ }^{64}$ nullity, ${ }^{65}$ and custody ${ }^{66}$ should have been taken as a warning. ${ }^{67}$

(2) Tentative Draft Number Two retains the First Restatement's concept of a unitary domicile in the black-letter text of section 11 ("no person has more than one domicile at the time"), but in effect negates that concept in the comments which concede the possibility that one may have different domiciles "under the laws of different states" and even "under the law of a single state" for different purposes. ${ }^{68}$

(3) Tentative Draft Number Four is based on a concept of a person's status independent from its incidents. It is maintained that "this status remains the same during his travels from state to state [although] the incidents arising under the status are likely to vary since they will often depend upon the law of the state where they are sought to be enjoyed." 89 The inconsistency in this statement is not removed by the subsequent sections.

(4) Tentative Draft Number Six on Contracts is of course almost entirely based on the repetition of the give-it-up formula of the "most significant relationship" and has therefore been severely criticized. ${ }^{70}$ It is admittedly the "proper law" theory of the Commonwealth countries and the "center of gravity" language of the New York Court of Appeals. The less than fortunate experience of that court alone ${ }^{71}$ should have prevented adoption of this approach which holds a serious danger. The Second Restatement formula can be used to support virtually any result and is thus bound to hamper the sound development of the common law by saving the court the difficult but necessary effort of articulating those true motivations which are of course the very elements of growing rules.

Those few provisions of the Draft which attempt more tangible solutions, are largely unsupported by authority. This applies to such

64 See Treatise $\$ \$ 71-78$.

65 See id. $\$ \S 91-92$.

${ }^{66}$ See id. $\$ \S 86-89$.

67 See text at notes $24-27$, supra regarding legislative jurisdiction; text at notes 55-63, supra concerning full faith and credit to judgments.

68 Restatement (Second), Conflict of Laws $\$ 11$, comments $c \& d$ (Tent. Draft No. 2, 1954).

69 Restatenent (Second), Conflict of Laws $\$ 119$, comment $a$ at 87 (Tent. Draft No. 4, 1957); see TrEatise $\$ 135$.

70 See, e.g., Cavers, Re-Stating the Conflict of Laws: The Chapter on Contracts, in XXth Century Consparative and Conflicts LaW 349, 364 (1961); Weintraub, The Contracts Proposal of the Second Restatement of Conflict of Lazes-A Critique, 46 Iowa L. REv. 713 (1961).

71 See Haag v. Barnes, 9 N.Y.2d 554, 216 N.Y.S.2d 65, 175 N.E.2d 441 (1961); cf. Ehrenzweig, The "Bastard" in the Conflict of Lares-A National Disgrace, 29 U. CHI. L. REV. 498 (1962). 
important propositions as those which postulate applicability of the validating law in the one situation in which it does not and should not apply, namely in the conflicts law governing the defense of usury; ${ }^{72}$ or of the law of the surrender of the chattel to breaches of warranty; ${ }^{73}$ or the law of the state of departure to contracts of transportation. ${ }^{\mathbf{7 4}}$

(5) Tentative Drafts Numbers Eight and Nine recommend adoption of the "most significant relationship" formula for what the Institute, in accord with the First Restatement, somewhat quaintly continues to designate as "Wrongs." These Drafts will thus not only share the problems of the Contracts chapter, but, in addition, lack even such tenuous support as that underlying that chapter. The Institute's recommendation will, therefore, have to be defended on the ground that, though concededly not restating existing law, it proposes desirable rules which in due course will be adopted by the courts. It is submitted that this defense, which in any event cannot properly support a purported "restatement," is hardly justified in light of the Institute's experience with its First Restatement.

\section{Desirable Law?}

The Restatement in the Courts $(1945,1948,1954)$ lists hundreds of cases which have cited the First Restatement of the Conflict of Laws. These listings are misleading and should be discontinued or at least explained. For only very few of them reflect adoption of the Institute's teaching. In the vast majority of the cases cited, there was no conflict or the court avoided the effect of the Restatement "rule" by such artificial devices as re-characterization, re-localization, renvoi or invocation of public policy. At least in conflicts law, it can hardly be said therefore, that "the story of what has been accomplished by the Restatement of the Law can best be told by statistics." 75

Owing to the vagueness of the Second Restatement's give-it-up formulas, any proof of that document's accomplishments based on a mechanical listing of the cases citing it, will be even less valid than has been the application of this method to vindicate the First Restatement. To be sure, justification of tort conflicts decisions as based on the Second Restatement's law of "the most significant relationship"

72 See Treatise $\S 182$.

73 Restatement (Second), Conflict of Laws $\$ 346 \mathrm{~g}$, comment $b$ (Tent. Draft No. 6,1960$)$.

74 Id. § 346n.

75 Goodrich, The Story of the American Law Institute, 1951 WASH. U.L.Q. $283,291$. 
will be harmless enough where the result thus reached accords with that postulated by current doctrine. Indeed, our brief experience so far has shown that the courts are inclined to use such a justification as an ever-fitting make-weight argument. ${ }^{76}$ But this is not always so. Thus, when a distinguished court recently relied on the Draft's facile formula in a case involving an insurer's liability for failure to act promptly, it may well thus have been precluded from reaching another result by failing to articulate the conflicting interests and policies. ${ }^{77}$

In those few instances in which the chapter on Wrongs undertakes to offer a more specific solution than its general formula, that solution is open to serious doubt. In the light of available authority it is quite doubtful whether, and if so when, a court will apply a law other than its own in fraud cases; ${ }^{78}$ whether the First Restatement's ${ }^{78}$ "authorization" test of vicarious liability can still be maintained even in a modified form; ${ }^{80}$ and whether in wrongful death cases the place of injury can still be given primary relevance. ${ }^{81}$ On the other hand, it seems hardly justifiable to make the give-it-up formula of "the most significant relationship" applicable to such problems as imputed negligence, $^{82}$ survival of actions, ${ }^{83}$ charitable immunity, ${ }^{84}$ or contribution between tortfeasors, ${ }^{85}$ where consistent court practice would permit more definite conclusions.

Judge Goodrich has stressed that "in conflict of laws the growth is faster than in some other places." 88 And Pennsylvania Supreme

76 See, e.g., Hardman v. Helene Curtis Indus., Inc., 48 Ill. App. 2d 42, 61 nn.*, 198 N.E.2d 681 , $690 \mathrm{nn} .8,9$ (1964), though relying substantially (id. at 60,198 N.E.2d at 689 ) on the calculability theory, TREATISE $\$ 223$, at 591. But see Wilcox v. Wilcox, 133 N.W.2d 408, 417 (Wis. 1965), expressing cautious reserve regarding the Second Restatement's list of "contacts" and relying with at least equal approval on three other theories including that of the author. Id. at 413.

77 Lowe's North Wilkesboro Hardware, Inc. v. Fiduciary Mut. Life Ins. Co., 319 F.2d 469, 473 n.7 (1963); cf. Ehrenzweig, The "Most Significant Relationship" in Conflicts Law of Torts, 28 LAW \& ConTeMrP. Prob. 700, 702-05 (1963).

78 Restatensent (Second), Conflict of Laws \$ 379c (Tent. Draft No. 9, 1964); cf. Treatise $\$ 215$, at 558-59.

79 Restatement, Conflict of Laws $\$ 387$ (1934).

80 Restatement (Second), Conflict of Laws \$ 390 f (Tent. Draft No. 9, 1964); cf. TREATISE $\$ \S 170,219$.

81 Restatement (Second), Conflict of Laws \$391 (Tent. Draft No. 9, 1964); cf. TREatise $\$ 213$, at 552-56.

82 Restatement (Second), Conflict of Laws \& 385b (Tent. Draft No. 9, 1964); cf. TREATISE $\$ 246$, at $652-53$.

83 Restatenent (Second), Conflict of Laws \$ 390 (Tent. Draft No. 9, 1964); $c f$. Treatise $\$ 103$, at 313 .

84 Restatement (Second), Conflict of Laws $\$ 390$ a (Tent. Draft No. 9, 1964); cf. Treatise $\$ 221$, at 583-84.

85 Restatenrent (Second), Conflict of Laws § 390d (Tent. Draft No. 9, 1964); cf. Treatise \$225, at 595-96.

86 Goodrich, Yielding Place to New: Rest Versis Motion in the Conflict of Laws, 50 Colum. L. ReV. 881,899 (1950). 
Court Justice Roberts, refuting the First Restatement, has recently welcomed a new stage of this growth:

We are at the beginning of the development of a workable fair and flexible approach to choice of law which will become more certain as it is tested and further refined when applied to specific cases before our courts. ${ }^{87}$

Surely, it is neither feasible nor desirable to "restate" a beginning.

87 Griffith v. United Air Lines, 416 Pa. 1, 203 A.2d 796 (1964). 